\title{
Burkholderia sabiae sp. nov., isolated from root nodules of Mimosa caesalpiniifolia
}

\author{
Wen-Ming Chen, ${ }^{1}$ Sergio M. de Faria, ${ }^{2}$ Jui-Hsing Chou, ${ }^{3}$ Euan K. James, ${ }^{4}$ \\ Geoffrey N. Elliott, ${ }^{4}$ Janet I. Sprent, ${ }^{4}$ Cyril Bontemps, ${ }^{5}$ J. Peter W. Young ${ }^{5}$ \\ and Peter Vandamme ${ }^{6}$ \\ ${ }^{1}$ Laboratory of Microbiology, Department of Seafood Science, National Kaohsiung Marine \\ University, 142 Hai-Chuan Rd, Nan-Tzu, Kaohsiung City 811, Taiwan \\ ${ }^{2}$ EMBRAPA-Agrobiologia, km 47, Seropedica, 23851-970 Rio de Janeiro, Brazil \\ ${ }^{3}$ Department of Soil Environmental Science, College of Agriculture and Natural Resources, National \\ Chung Hsing University, Taichung, Taiwan \\ ${ }^{4}$ College of Life Sciences, University of Dundee, Dundee DD1 5EH, UK \\ ${ }^{5}$ Department of Biology, University of York, PO Box 373, York YO10 5YW, UK \\ ${ }^{6}$ Laboratorium voor Microbiologie, Universiteit Gent, K. L. Ledeganckstraat 35, B-9000 Gent, \\ Belgium
}

Correspondence

Wen-Ming Chen p62365@ms28.hinet.net
Plants in the legume genus Mimosa (in the subfamily Mimosoideae) are largely nodulated by members of the Betaproteobacteria, such as Cupriavidus taiwanensis and Burkholderia strains (Chen et al., 2001, 2003a, b, 2005a, b; Vandamme \& Coenye, 2004; Verma et al., 2004; Barrett \& Parker, 2005, 2006; Elliott et al., 2007). Symbiont diversity within the genus Cupriavidus appears to be quite low based upon $16 \mathrm{~S}$ rRNA gene sequences, and only one nodulating species of Cupriavidus, C. taiwanensis (Chen et al., 2001), has been described so far. However, in contrast to Cupriavidus, the diversity of Burkholderia symbionts associated with legumes is very high (Chen et al., 2005a, b; Barrett \& Parker, 2005, 2006), and two novel Mimosanodulating species, Burkholderia mimosarum (Chen et al., 2006) and Burkholderia nodosa (Chen et al., 2007), have recently been added to the genus. Together with

Abbreviation: PFGE, pulsed-field gel electrophoresis.

The GenBank/EMBL/DDBJ accession numbers for the $16 \mathrm{~S}$ rRNA gene sequences of strains $\mathrm{Br} 3407^{\top}$ and $\mathrm{Br} 3405$ are respectively AY773186 and AY773185.

An extended neighbour-joining tree, detailed DNA-DNA hybridization results and fatty acid compositions of strain $\mathrm{Br} 3407^{\top}$ and related strains are available as supplementary material with the online version of this paper.
Burkholderia phymatum and Burkholderia tuberum (Moulin et al., 2001; Vandamme et al., 2002), this brings the number of legume-nodulating Burkholderia species to four, but 16S rRNA gene sequences in the literature and databases suggest that several other species await description. For example, amongst the group of South American Mimosa symbionts described by Chen et al. (2005a) that gave rise to both $B$. mimosarum and B. nodosa (Chen et al., $2006,2007)$, there are other clades containing strains that cluster very closely together. In this paper, we describe a novel Mimosa-nodulating species based upon two strains, $\mathrm{Br} 3405$ and $\mathrm{Br} 3407^{\mathrm{T}}$, both isolated from Mimosa caesalpiniifolia, a legume tree native to Brazil.

Both Br3405 and Br3407 ${ }^{\mathrm{T}}$ were grown on yeast extractmannitol agar plates (Vincent, 1970) and incubated at $28{ }^{\circ} \mathrm{C}$ unless otherwise indicated. Burkholderia reference strains have been described previously (Achouak et al., 1999; Vandamme et al., 2002; Goris et al., 2002; Yang et al., 2006).

The 16S rRNA gene sequences of strains $\mathrm{Br} 3407^{\mathrm{T}}$ and Br3405 have been reported by Chen et al. (2005a). $16 \mathrm{~S}$ rRNA gene sequences of related taxa were obtained from the Ribosomal Database Project and GenBank databases. 
Multiple alignments were performed by using the CLUSTAL_X program (Thompson et al., 1997) and gaps were edited in the BioEdit program, version 5.0.9 (Hall, 1999). Evolutionary distances were calculated using Kimura's two-parameter model (Kimura, 1983). Phylogenetic trees were constructed by the neighbourjoining (Saitou \& Nei, 1987) and maximum-parsimony (Fitch \& Margoliash, 1967) methods, using the MEGA program, version 3.1 (Kumar et al., 2004), and with bootstrap values based on 1000 replications (Felsenstein, 1981). The 16S rRNA gene sequence similarity between strains $\mathrm{Br} 3407^{\mathrm{T}}$ and $\mathrm{Br} 3405$ was $99.7 \%$. In the phylogenetic tree based on the neighbour-joining algorithm, strains $\mathrm{Br} 3407^{\mathrm{T}}$ and $\mathrm{Br} 3405$ formed a well-supported clade with type strains of $B$. phymatum, Burkholderia caribensis, Burkholderia terrae and Burkholderia hospita (Fig. 1 and Supplementary Fig. S1, available in IJSEM Online). The 16S rRNA gene sequence of strain $\mathrm{Br} 3407^{\mathrm{T}}$ has 98.5, 98.5, 98.2 and $97.8 \%$ similarity, respectively, to these four type strains, and similarity of $97.8-97.0 \%$ to the type strains of Burkholderia terricola, B. fungorum, B. phenoliruptrix, B. phytofirmans, B. xenovorans, B. graminis, B. caryophylli and B. caledonica. The similarity to other Burkholderia species is less than $97.0 \%$.

DNA samples were prepared from strains $\mathrm{Br} 3407^{\mathrm{T}}$ and Br3405 as described by Pitcher et al. (1989). For determination of the DNA base composition, DNA was degraded enzymically into nucleosides as described by Mesbah et al. (1989). The nucleoside mixture was separated by HPLC using a Waters Symmetry Shield $\mathrm{C} 8$ column at $37{ }^{\circ} \mathrm{C}$. The solvent was $0.02 \mathrm{M} \mathrm{NH} \mathrm{NH}_{4} \mathrm{H}_{2} \mathrm{PO}_{4}$ (pH 4.0) with $1.5 \%$ acetonitrile. Non-methylated lambda phage DNA (Sigma) was used as the calibration reference. DNA-DNA hybridizations were performed with photobiotin-labelled probes as

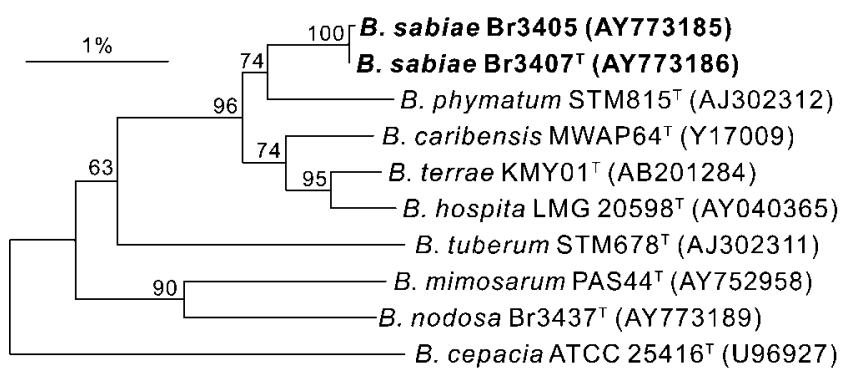

Fig. 1. Phylogenetic tree of strains $\mathrm{Br} 3407^{\top}$ and $\mathrm{Br} 3405$ (Burkholderia sabiae sp. nov.) and related Burkholderia type strains based on 16S rRNA gene sequence comparisons. Distances were calculated and clustering with the neighbourjoining method was performed by using the software package BioEdit. Numbers at nodes are percentage bootstrap values based on 1000 resampled datasets; only values $>50 \%$ are given. Bar, $1 \%$ sequence dissimilarity. The sequence of Burkholderia cepacia ATCC $25416^{\top}$ was used as an outgroup. A tree including a wider selection of reference sequences is available as Supplementary Fig. S1 in IJSEM Online. described by Ezaki et al. (1989). The hybridization temperature was $50{ }^{\circ} \mathrm{C}$ and the reaction was carried out in $30 \%$ formamide. Each value obtained was the mean of two hybridization experiments. The DNA G+C content of strains $\mathrm{Br} 3407^{\mathrm{T}}$ and $\mathrm{Br} 3405$ was $64.0 \pm 0.5 \mathrm{~mol} \%$. The DNA-DNA binding value between strains $B r 3407^{\mathrm{T}}$ and Br3405 was $97-100 \%$ (Supplementary Table S1). The high degree of DNA-DNA relatedness and the high levels of $16 \mathrm{~S}$ rRNA gene similarity between the two isolates indicate that they represent a single species. Their separate species status was demonstrated by the DNA-DNA hybridization values of $15-43 \%$ between strain $\mathrm{Br} 3407^{\mathrm{T}}$ and its closest phylogenetic neighbours, the type strains of $B$. phymatum, $B$. terrae, $B$. caribensis and B. hospita (Supplementary Table S1).

Differentiation of the proposed novel taxon from its closest phylogenetic neighbours was examined by several approaches. For the analysis of protein electrophoretic patterns, strains were grown on nutrient agar (Oxoid CM3) supplemented with $0.04 \%(\mathrm{w} / \mathrm{v}) \mathrm{KH}_{2} \mathrm{PO}_{4}$ and $0.24 \%(\mathrm{w} / \mathrm{v})$ $\mathrm{Na}_{2} \mathrm{HPO}_{4} \cdot 12 \mathrm{H}_{2} \mathrm{O}(\mathrm{pH} 6.8)$ and incubated for $48 \mathrm{~h}$ at $28{ }^{\circ} \mathrm{C}$. Preparation of whole-cell proteins and SDS-PAGE were performed as described by Pot et al. (1994). Densitometric analysis, normalization and interpolation of the protein profiles and numerical analysis using Pearson's product-moment correlation coefficient were performed using the GelCompar 4.2 software package (Applied Maths). Whole-cell protein extracts were prepared from strains $\mathrm{Br} 3407^{\mathrm{T}}$ and $\mathrm{Br} 3405$ and compared with others present in our database. Strains $\mathrm{Br} 3407^{\mathrm{T}}$ and $\mathrm{Br} 3405$ formed a single cluster with similarities of $>98 \%$, in comparison with similarities of less than $79 \%$ to other Burkholderia species (Fig. 2). For pulsed-field gel electrophoresis (PFGE) genome organization analysis as described by Chen et al. (2003b), intact genomic DNA in agarose plugs was electrophoresed on an $0.8 \%$ agarose gel in TAE for $41 \mathrm{~h}$ with a pulse time of $500 \mathrm{~s}$ at $100 \mathrm{~V}$ (CHEF-III system; Bio-Rad). Strains $\mathrm{Br} 3407^{\mathrm{T}}$ and $\mathrm{Br} 3405$ have similar PFGE profiles and contained three replicons $(5.0-5.2,2.4-$ 2.6 and $0.5-0.6 \mathrm{Mb}$ ). The PFGE profiles of the two Mimosa isolates clearly differentiate them from their closest neighbour, the type strain of $B$. phymatum, which contained four replicons of 3.5, 2.8, 2.0 and $0.5 \mathrm{Mb}$ (Chen et al., 2003b) (Fig. 3).

For fatty acid methyl ester analysis, cells were harvested after an incubation period of $48 \mathrm{~h}$ at $28{ }^{\circ} \mathrm{C}$; fatty acid methyl esters were then prepared, separated and identified using the Microbial Identification System (Microbial ID) as described previously (Vandamme et al., 2002). Fatty acid profiles of strains $\mathrm{Br} 3407^{\mathrm{T}}$ and $\mathrm{Br} 3405$ were determined and compared with those of other Burkholderia species. Fatty acid profiles of strains $\mathrm{Br} 3407^{\mathrm{T}}$ and $\mathrm{Br} 3405$ and other reference strains were similar, and were dominated by $16: 0,18: 1 \omega 7 c$, summed feature 2 (any combination of 14:03-OH, 16:1 iso I, an unidentified fatty acid with an equivalent chainlength of 10.928 or 12:0 ALDE) and summed feature 3 $(16: 1 \omega 7 c$ and/or $15: 0$ iso $2-\mathrm{OH})$, which supported the affiliation of strains $\mathrm{Br} 3407^{\mathrm{T}}$ and $\mathrm{Br} 3405$ to the genus 

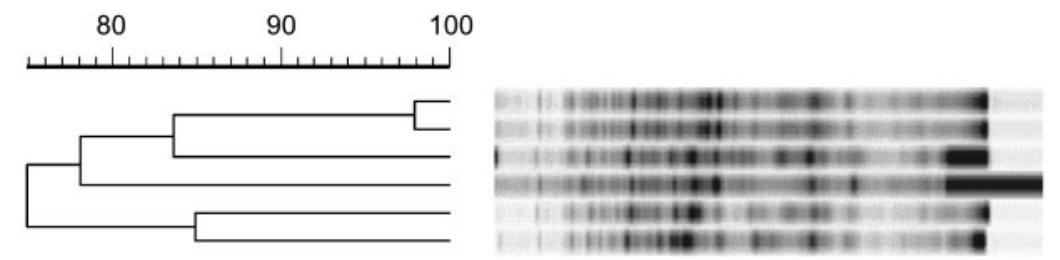

B. sabiae $\mathrm{Br} 3405$

B. sabiae Br3407'

B. terrae LMG $23368^{\mathrm{T}}$

B. hospita LMG 20574

B. caribensis LMG $18531^{\top}$

B. phymatum LMG $21445^{\top}$

Fig. 2. Dendrogram based on numerical analysis of the whole-cell protein profiles of Mimosa isolates $\left(\mathrm{Br} 3407^{\top}\right.$ and $\left.\mathrm{Br} 3405\right)$ and type strains of closely related Burkholderia species.

Burkholderia (Supplementary Table S2). In general, all these organisms had very similar whole-cell fatty acid profiles, which were not useful for species discrimination. The fatty acid profile of strain $\mathrm{Br} 3407^{\mathrm{T}}$ consisted of $14: 0$ $(3.7 \pm 0.1 \%), \quad 16: 0 \quad(17.9 \pm 0.4 \%), \quad 18: 0 \quad(1.4 \pm 0.2 \%)$, $17: 0 \quad$ cyclo $\quad(3.7 \pm 0.3 \%), \quad 16: 0 \quad 3-\mathrm{OH} \quad(4.1 \pm 0.1 \%)$, $18: 1 \omega 7 c(43.1 \pm 1.0 \%), 19: 0$ cyclo $\omega 8 c(3.3 \pm 0.2 \%)$ and summed features $2(5.0 \pm 0.1 \%)$ and $3(16.0 \pm 0.5 \%)$.

Cell morphology was examined by phase-contrast microscopy (DM 2000; Leica) in the lag, exponential and stationary phases of growth. A Gram-stain set (BD Difco) and the Ryu non-staining KOH method (Powers, 1995) were used to ascertain the Gram reaction. The motility of cells was tested by using the hanging drop method. Poly- $\beta$ hydroxybutyrate granule accumulation was observed under

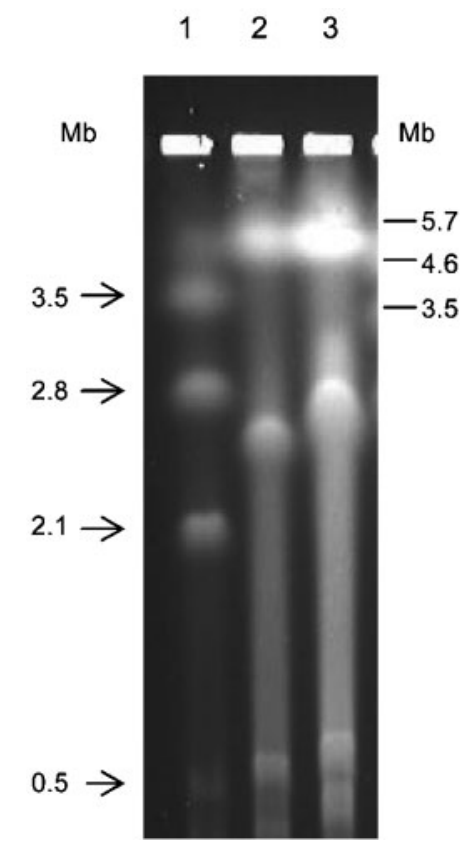

Fig. 3. PFGE of undigested whole-genome DNA profiles. Lanes: 1, B. phymatum STM815 ${ }^{\top}$ (sizes of replicons are indicated on the left); 2, strain Br3405; 3, strain $\mathrm{Br}_{4407^{\top}}$. Molecular sizes of Schizosaccharomyces pombe marker DNA (Bio-Rad) are indicated on the right. light microscopy after staining of cells with Sudan black. Catalase activity was determined by bubble production in a $3 \%(\mathrm{v} / \mathrm{v}) \mathrm{H}_{2} \mathrm{O}_{2}$ solution. Oxidase activity was determined on filter paper moistened with a $1 \%(\mathrm{w} / \mathrm{v})$ aqueous solution of $N, N, N^{\prime}, N^{\prime}$-tetramethyl-p-phenylenediamine.

For biochemical characterization, the API 20NE and API ZYM microtest systems were used according to the recommendations of the manufacturer (bioMérieux). For carbon substrate assimilation tests, Biolog GN2 microtitre test plates were used. B. phymatum LMG $21445^{\mathrm{T}}, B$. caribensis LMG $18531^{\mathrm{T}}$, B. hospita LMG $20598^{\mathrm{T}}$ and $B$. terrae LMG $23368^{\mathrm{T}}$ were included as reference strains.

When using the API 20NE microtest gallery, the following characteristics were present in all strains: nitrate reduction, activity of oxidase, catalase, urease and $\beta$-galactosidase and assimilation of glucose, arabinose, mannose, mannitol, $\mathrm{N}$ acetylglucosamine, gluconate, caprate, citrate, malate and phenylacetate. The following characteristics were uniformly absent: indole production, glucose fermentation, aesculin hydrolysis, gelatin hydrolysis and assimilation of adipate and maltose.

When using the API ZYM microtest gallery, activities of alkaline phosphatase, C4 esterase, C8 lipase, leucine arylamidase, acid phosphatase and naphthol-AS-BI-phosphohydrolase were present in all strains. Activities of C14 lipase, valine arylamidase, cystine arylamidase, trypsin, $\alpha$ chymotrypsin, $\alpha$-galactosidase, $\beta$-galactosidase, $\beta$-glucuronidase, $\alpha$-glucosidase, $\beta$-glucosidase, $N$-acetyl- $\beta$-glucosaminidase, $\alpha$-mannosidase and $\alpha$-fucosidase were uniformly absent.

Detailed results of the biochemical characterization and antibiotic sensitivity tests are given in Table 1 and in the species description. Strain $\mathrm{Br} 3407^{\mathrm{T}}$ can be distinguished from representatives of its close phylogenetic relatives by using a combination of phenotypic attributes, especially nitrate reduction, activity of urease, arginine dihydrolase, esterase C4 and esterase lipase C8 and oxidation of various substrates (Table 1). Strain $\mathrm{Br} 3407^{\mathrm{T}}$ had been shown previously to form $\mathrm{N}_{2}$-fixing nodules on four Mimosa species, but not on its original host (Chen et al., 2005a; Table 1). Therefore, it was inoculated on to M. caesalpiniifolia seedlings according to Elliott et al. (2007) and, after 6 months growth, it was shown to produce very active 
Table 1. Comparison of phenotypic characters of strain $B r 3407^{\top}$ and the type strains of related Burkholderia species

Strains: 1, strain Br3407 ${ }^{\mathrm{T}}$ (B. sabiae sp. nov.); 2, B. phymatum LMG $21445^{\mathrm{T}}$; 3, B. caribensis LMG $18531^{\mathrm{T}}$; 4, B. hospita LMG $20598^{\mathrm{T}}$; 5, B. terrae LMG $23368^{\mathrm{T}}$. +, Positive; - , negative; w, weak reaction. Data for reference strains were obtained in this study with the exception of sources of isolation and DNA G + C contents, which were taken from Vandamme et al. (2002), Achouak et al. (1999), Goris et al. (2002) and Yang et al. (2006). All the strains have the following features: positive for the oxidation of Tweens 40 and $80, \mathrm{~N}$-acetyl-D-glucosamine, adonitol, D-arabitol, Dfructose, L-fucose, D-galactose, $\alpha$-D-glucose, myo-inositol, D-mannitol, D-mannose, L-rhamnose, D-sorbitol, pyruvic acid methyl ester, succinic acid monomethyl ester, cis-aconitic acid, formic acid, D-galactonic acid lactone, D-gluconic acid, D-glucosaminic acid, D-glucuronic acid, $\beta$ hydroxybutyric acid, $p$-hydroxyphenylacetic acid, DL-lactic acid, quinic acid, succinic acid, bromosuccinic acid, L-alanyl glycine, L-asparagine, Laspartic acid, L-glutamic acid, L-histidine, L-leucine, L-phenylalanine, L-proline, L-pyroglutamic acid, $\gamma$-aminobutyric acid and 2-aminoethanol. Negative for the oxidation of $\alpha$-cyclodextrin, i-erythritol, gentiobiose, maltose, methyl $\beta$-D-glucoside, raffinose, $\gamma$-hydroxybutyric acid, itaconic acid, $\alpha$-ketovaleric acid, uridine, thymidine and putrescine.

\begin{tabular}{|c|c|c|c|c|c|}
\hline Characteristic & 1 & 2 & 3 & 4 & 5 \\
\hline Isolation source & Root nodules & Root nodules & Soil & Soil & Soil \\
\hline Nitrate reduction & + & + & + & + & - \\
\hline Arginine dihydrolase & - & - & + & - & + \\
\hline Esterase C4 & + & - & + & + & - \\
\hline Esterase lipase C8 & + & - & - & - & + \\
\hline Dextrin & $\mathrm{W}$ & - & - & - & - \\
\hline Glycogen & $\mathrm{W}$ & - & - & - & - \\
\hline$N$-Acetyl-D-galactosamine & - & - & $\mathrm{w}$ & - & + \\
\hline L-Arabinose & + & + & + & - & + \\
\hline Lactulose & + & - & + & - & + \\
\hline D-Psicose & - & + & w & - & + \\
\hline Glycyl L-glutamic acid & + & - & - & - & + \\
\hline L-Ornithine & - & $\mathrm{w}$ & - & + & + \\
\hline D-Serine & + & $\mathrm{w}$ & - & $\mathrm{w}$ & + \\
\hline Inosine & $\mathrm{w}$ & - & + & - & + \\
\hline Glycerol & $\mathrm{W}$ & - & + & + & + \\
\hline DL- $\alpha$-Glycerol phosphate & - & - & + & - & + \\
\hline Nodulation on Mimosa pudica & + & + & - & - & - \\
\hline DNA G + C content (mol\%) & 64.5 & 62.1 & 63.1 & 62.0 & 62.0 \\
\hline
\end{tabular}

nodules giving high acetylene reduction activities $\left(3.776 \pm 1.542 \mathrm{nmol} \mathrm{C}_{2} \mathrm{H}_{4} \mathrm{~h}^{-1}\right.$ per plant).

In conclusion, the present study demonstrated that the two isolates from root nodules of $M$. caesalpiniifolia from Brazil represent a single species that is readily distinguished from its nearest phylogenetic neighbours by whole-cell protein profiles (Fig. 2), whole-genome PFGE patterns (Fig. 3), DNA-DNA reassociation experiments (Supplementary Table S1) and biochemical characterization (Table 1). Moreover, strain $\mathrm{Br} 3407^{\mathrm{T}}$ effectively nodulated its original host, M. caesalpiniifolia, and other Mimosa species (Table 1), and the presence of nif and nod genes in the genome of strain Br3407 ${ }^{\mathrm{T}}$ has been demonstrated (Chen et al., 2005a). We propose the name Burkholderia sabiae sp. nov. Two other strains with $16 \mathrm{~S}$ rRNA gene sequences that are closely related to those of strains Br3405 and $\mathrm{Br} 3407^{\mathrm{T}}$, strain Br3446 isolated from Mimosa laticifera (Chen et al., 2005a) and Br3452 isolated from M. caesalpiniifolia (Menna et al., 2006), were not included in this study as Br3452 could not be obtained and the protein profile of Br3446 was very different from those of Br3405 and

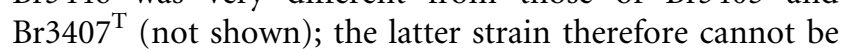
considered to be a third strain of B. sabiae.

\section{Description of Burkholderia sabiae sp. nov.}

Burkholderia sabiae (sa'bi.ae. N.L. gen. n. sabiae from sabiá, the Portuguese name of Mimosa caesalpiniifolia, the tree from which the type strain was isolated).

Cells are Gram-negative, non-spore-forming rods. Poly- $\beta$ hydroxybutyrate granules are accumulated. After $24 \mathrm{~h}$ growth on yeast extract-mannitol agar at $28{ }^{\circ} \mathrm{C}$, the mean cell size is about $0.4-0.6 \times 0.6-1.5 \mu \mathrm{m}$. Growth is observed at 28, 30 and $37{ }^{\circ} \mathrm{C}$. Catalase- and oxidase-positive. Assimilation of glucose, arabinose, mannose, mannitol, 
$\mathrm{N}$-acetylglucosamine, gluconate, caprate, citrate, malate and phenylacetate is observed. No indole production, gelatin hydrolysis, aesculin hydrolysis, glucose fermentation or assimilation of adipate or maltose is observed. The following carbon sources are oxidized (positive in the Biolog GN2 system): dextrin, glycogen, Tweens 40 and 80, $\mathrm{N}$-acetyl-D-glucosamine, adonitol, arabinose, arabitol, cellobiose, D-fructose, L-fucose, D-galactose, lactulose, $\alpha$ D-glucose, myo-inositol, D-mannitol, D-mannose, L-rhamnose, D-sorbitol, trehalose, methyl pyruvate, monomethyl succinate, acetic acid, cis-aconitic acid, citrate, formic acid, D-galactonic acid lactone, D-galacturonic acid, Dgluconic acid, D-glucosaminic acid, D-glucuronic acid, $\alpha$ hydroxybutyric acid, $\beta$-hydroxybutyric acid, $p$-hydroxyphenylacetic acid, $\alpha$-ketobutyric acid, $\alpha$-ketoglutaric acid, DL-lactate, malonic acid, propionic acid, quinic acid, D-saccharic acid, succinic acid, bromosuccinic acid, succinamic acid, glucuronamide, alaninamide, D- and Lalanine, L-alanyl glycine, L-asparagine, L-aspartic acid, Lglutamic acid, glycyl L-aspartic acid, glycyl L-glutamic acid, L-histidine, L-leucine, L-phenylalanine, L-proline, L-pyroglutamic acid, L- and D-serine, L-threonine, DLcarnitine, $\gamma$-aminobutyric acid, inosine, phenylethylamine, 2-aminoethanol, glycerol and glucose 6-phosphate. The following substrates are not utilized as carbon sources (negative in the Biolog GN2 system): $\alpha$-cyclodextrin, $N$-acetyl-D-galactosamine, i-erythritol, gentiobiose, $\alpha$-Dlactose, maltose, melibiose, methyl $\beta$-D-glucoside, Dpsicose, raffinose, sucrose, turanose, xylitol, $\gamma$-hydroxybutyric acid, itaconic acid, $\alpha$-ketovaleric acid, sebacic acid, Lornithine, urocanic acid, uridine, thymidine, putrescine, 2,3-butanediol, DL- $\alpha$-glycerol phosphate and glucose 1phosphate. Sensitive to amikacin $(30 \mu \mathrm{g})$, cefotaxime $(30 \mu \mathrm{g})$, chloramphenicol $(30 \mu \mathrm{g})$, kanamycin $(30 \mu \mathrm{g})$, nalidixic acid $(30 \mu \mathrm{g})$, novobiocin $(30 \mu \mathrm{g})$, piperacillin $(100 \mu \mathrm{g})$, rifampicin $(5 \mu \mathrm{g})$, streptomycin $(10 \mu \mathrm{g})$ and tetracycline $(30 \mu \mathrm{g})$. Known strains were isolated from root nodules of Mimosa caesalpiniifolia.

The type strain is strain $\mathrm{Br} 3407^{\mathrm{T}}$ (=LMG $24235^{\mathrm{T}}=\mathrm{BCRC}$ $\left.17587^{\mathrm{T}}\right)$. Phenotypic characteristics of the type strain are the same as described for the species. Its DNA G+C content is $64.5 \mathrm{~mol} \%$ and the genome size is approximately $8 \mathrm{Mb}$.

\section{Acknowledgements}

W.-M. C. was supported by grants from the National Science Council, Taipei, Taiwan, Republic of China (NSC 96-2320-B-022-001-MY2 and 96-2313-B-022-001) and E.K.J., G.N.E., J.I.S., C.B. and J.P.W.Y. were supported by the Natural Environment Research Council (NERC), UK (NE/B505038/1 and NE/B505046/1).

\section{References}

Achouak, W., Christen, R., Barakat, M., Martel, M. H. \& Heulin, T. (1999). Burkholderia caribensis sp. nov., an exopolysaccharideproducing bacterium isolated from vertisol microaggregates in Martinique. Int J Syst Bacteriol 49, 787-794.
Barrett, C. F. \& Parker, M. A. (2005). Prevalence of Burkholderia sp. nodule symbionts on four mimosoid legumes from Barro Colorado Island, Panama. Syst Appl Microbiol 28, 57-65.

Barrett, C. F. \& Parker, M. A. (2006). Coexistence of Burkholderia, Cupriavidus and Rhizobium sp. nodule bacteria on two Mimosa spp. in Costa Rica. Appl Environ Microbiol 72, 1198-1206.

Chen, W. M., Laevens, S., Lee, T. M., Coenye, T., De Vos, P., Mergeay, M. \& Vandamme, P. (2001). Ralstonia taiwanensis sp. nov., isolated from root nodules of Mimosa species and sputum of a cystic fibrosis patient. Int J Syst Evol Microbiol 51, 1729-1735.

Chen, W. M., James, E. K., Prescott, A. R., Kierans, M. \& Sprent, J. I. (2003a). Nodulation of Mimosa spp. by the $\beta$-proteobacterium Ralstonia taiwanensis. Mol Plant Microbe Interact 16, 1051-1061.

Chen, W. M., Moulin, L., Bontemps, C., Vandamme, P., Béna, G. \& Boivin-Masson, C. (2003b). Legume symbiotic nitrogen fixation by $\beta$-Proteobacteria is widespread in nature. J Bacteriol 185, 7266-7272.

Chen, W. M., de Faria, S. M., Straliotto, R., Pitard, R. M., SimoesAraujo, J. L., Chou, J. H., Chou, Y. J., Barrios, E., Prescott, A. R. \& other authors (2005a). Proof that Burkholderia strains form effective symbioses with legumes: a study of novel Mimosa-nodulating strains from South America. Appl Environ Microbiol 71, 7461-7471.

Chen, W. M., James, E. K., Chou, J. H., Sheu, S. Y., Yang, S. Z. \& Sprent, J. I. (2005b). $\beta$-Rhizobia from Mimosa pigra, a newly discovered invasive plant in Taiwan. New Phytol 168, 661-675.

Chen, W. M., James, E. K., Coenye, T., Chou, J. H., Barrios, E., de Faria, S. M., Elliott, G. N., Sheu, S. Y., Sprent, J. I. \& Vandamme, P. (2006). Burkholderia mimosarum sp. nov., isolated from root nodules of Mimosa spp. from Taiwan and South America. Int J Syst Evol Microbiol 56, 1847-1851.

Chen, W. M., de Faria, S. M., James, E. K., Elliott, G. N., Lin, K. Y., Chou, J. H., Sheu, S. Y., Cnockaert, M., Sprent, J. I. \& Vandamme, P. (2007). Burkholderia nodosa sp. nov., isolated from root nodules of the woody Brazilian legumes Mimosa bimucronata and Mimosa scabrella. Int J Syst Evol Microbiol 57, 1055-1059.

Elliott, G. N., Chen, W. M., Chou, J. H., Wang, H. C., Sheu, S. Y., Perin, L., Reis, V. M., Moulin, L., Simon, M. F. \& other authors (2007). Burkholderia phymatum is a highly effective nitrogen-fixing symbiont of Mimosa spp. and fixes nitrogen ex planta. New Phytol 173, 168-180.

Ezaki, T., Hashimoto, Y. \& Yabuuchi, E. (1989). Fluorometric deoxyribonucleic acid-deoxyribonucleic acid hybridization in microdilution wells as an alternative to membrane filter hybridization in which radioisotopes are used to determine genetic relatedness among bacterial strains. Int J Syst Bacteriol 39, 224-229.

Felsenstein, J. (1981). Evolutionary trees from DNA sequences: a maximum likelihood approach. J Mol Evol 17, 368-376.

Fitch, W. M. \& Margoliash, E. (1967). Construction of phylogenetic trees: a method based on mutation distances as estimated from cytochrome $c$ sequences is of general applicability. Science 155, 279-284.

Goris, J., Dejonghe, W., Falsen, E., De Clerck, E., Geeraerts, B., Willems, A., Top, E. M., Vandamme, P. \& De Vos, P. (2002). Diversity of transconjugants that acquired plasmid pJP4 or pEMT1 after inoculation of a donor strain in the A- and B-horizon of an agricultural soil and description of Burkholderia hospita sp. nov. and Burkholderia terricola sp. nov. Syst Appl Microbiol 25, 340-352.

Hall, T. A. (1999). BioEdit: a user-friendly biological sequence alignment editor and analysis program for Windows 95/98/NT. Nucleic Acids Symp Ser 41, 95-98.

Kimura, M. (1983). The Neutral Theory of Molecular Evolution. Cambridge: Cambridge University Press.

Kumar, S., Tamura, K. \& Nei, M. (2004). MEGA3: integrated software for molecular evolutionary genetics analysis and sequence alignment. Brief Bioinform 5, 150-163. 
Menna, P., Hungria, M., Barcellos, F. G., Bangel, E. V., Hess, P. N. \& Martinez-Romero, E. (2006). Molecular phylogeny based on the $16 \mathrm{~S}$ rRNA gene of elite rhizobial strains used in Brazilian commercial inoculants. Syst Appl Microbiol 29, 315-332.

Mesbah, M., Premachandran, U. \& Whitman, W. B. (1989). Precise measurement of the $\mathrm{G}+\mathrm{C}$ content of deoxyribonucleic acid by highperformance liquid chromatography. Int J Syst Bacteriol 39, 159-167.

Moulin, L., Munive, A., Dreyfus, B. \& Boivin-Masson, C. (2001). Nodulation of legumes by members of the $\beta$-subclass of proteobacteria. Nature 411, 948-950.

Pitcher, D. G., Saunders, N. A. \& Owen, R. J. (1989). Rapid extraction of bacterial genomic DNA with guanidium thiocyanate. Lett Appl Microbiol 8, 151-156.

Pot, B., Vandamme, P. \& Kersters, K. (1994). Analysis of electrophoretic whole-organism protein fingerprints. In Modern Microbial Methods (Chemical Methods in Prokaryotic Systematics Series), pp. 493-521. Edited by M. Goodfellow \& A. G. O’Donnell. Chichester: Wiley.

Powers, E. M. (1995). Efficacy of the Ryu nonstaining KOH technique for rapidly determining gram reactions of food-borne and waterborne bacteria and yeasts. Appl Environ Microbiol 61, 3756-3758.
Saitou, N. \& Nei, M. (1987). The neighbor-joining method: a new method for constructing phylogenetic trees. Mol Biol Evol 4, 406-425.

Thompson, J. D., Gibson, T. J., Plewniak, F., Jeanmougin, F. \& Higgins, D. G. (1997). The CLUSTAL_X windows interface: flexible strategies for multiple sequence alignment aided by quality analysis tools. Nucleic Acids Res 25, 4876-4882.

Vandamme, P. \& Coenye, T. (2004). Taxonomy of the genus Cupriavidus: a tale of lost and found. Int J Syst Evol Microbiol 54, 2285-2289.

Vandamme, P., Goris, J., Chen, W. M., de Vos, P. \& Willems, A. (2002). Burkholderia tuberum sp. nov. and Burkholderia phymatum sp. nov. nodulate the roots of tropical legumes. Syst Appl Microbiol 25, 507-512.

Verma, S. C., Chowdhury, S. P. \& Tripathi, A. K. (2004). Phylogeny based on 16S rRNA gene and nifH sequences of Ralstonia taiwanensis strains isolated from nitrogen-fixing nodules of Mimosa pudica, in India. Can J Microbiol 50, 313-322.

Vincent, J. M. (editor) (1970). A Manual for the Practical Study of the Root-Nodule Bacteria. Oxford: Blackwell Scientific.

Yang, H. C., Im, W. T., Kim, K. K., An, D. S. \& Lee, S. T. (2006). Burkholderia terrae sp. nov., isolated from a forest soil. Int J Syst Evol Microbiol 56, 453-457. 